\title{
CONTROLLING OF TOMATO EARLY BLIGHT DISEASE USING SOME OF BIOTIC AND A BIOTIC AGENTS Atia, M.M.M. ${ }^{*}$ and Amal A. M. Ahmed \\ Agric. Bot. Dept., Fac. Agric., Zagazig Univ., Zagazig, Egypt, \\ Fax: 0552287567, em@il:usamaatia2@yahoo.com \\ *Agric. Res. Center, Giza, Egypt
}

\begin{abstract}
Tomato (Lycopersicon esculentum Mill.) early blight caused by Alternaria solani is one of the most important economic diseases, which causing considerable loss in their yield and quality. Trichoderma viride, Bacillus subtilus and actinomycetes isolate A were the most effective bioagents on decreasing linear growth of $A$. solani. All bioagents tested reduced disease incidence using detached leaf and/or intact leaf techniques, when treated 2 and 7 days before inoculation with the pathogen. $T$. harizanum was the most effective isolate on reducing percentage of disease protection 2 and 7 days before inoculation (96.57 and 89.84) followed by $T$. viride $(92.65$ and $83.77 \%)$ then B. subtilus (83.34 and 66.89$)$ using detached leaf. The same trend was obtained in case intact leaf, $T$. harizanum was the most effective isolate on reducing disease severity, percentage of disease and increase percentage of protection 2 and 7 days before inoculation (16.44 and 58.62 and 38.28 at two days and 22.26, 62.43 and 35.17 afeter 7 days) followed by B. subtilus then $T$. viride. Generally bioagents tested were most effective using detached leaf than intact leaf.

In vitro experiments, chitosan and salicylic acid (SA) $4 \%$ were the effective concentrations on reducing growth of $A$. solani ( 84.44 and $67.77 \%$ ) and reducing spores germination (55.31 and $81.56 \%$ ). All the tested concentrations of chitosan and $\mathrm{SA}$ as inducer of resistance in tomato plants, which reduced number and diameter of lesion as well as percentage of disease and increase percentage of protection 7 days after treatment using detached and intact leaf techniques. Both water and ethanol extracts of garlic were the most effective on inhibition the mycelial growth, spore germination and disease parameters using detached and intact leaf techniques, followed by ginger extract.
\end{abstract}

Keywords: Bio-control, induced resistance, plant extracts, early blight, Alternaria solani, bio-control induced resistance, tomato.

\section{INTRODUCTION}

Early blight of tomato caused by the necrotrophic fungus Alternaria solani (Ellis \& Martin) Jones \& Grout, is one of the most common diseases of tomatoes. The disease can occur over a wide range of climatic conditions, but it is most iprominent in areas with dew, rainfull and high relative humidity. On tomato, infection of the plants can result in a complete loss of the crop as yields are reduced by damaging foliage and fruits (Chaerani et al. 2007).

In the recent years, there are an environmental and economical concerns regarding agricultural chemicals have resulted in searching of alternative disease control agents that minimize fungicides use without increasing disease losses i.e. bio-agents (Atia, 2005, Taghian, Shadia, et.al. 2008 and Esh et al., 2010), essential plant extracts and systemic inducers of resistance, which were, safe for men and environmental, has long lasting activity and effective against wide rang of pathogen (Kessman et. al., 1994 and Van Loon et.al. 1997). 
Several investigators used plant surface flora as a bioagent against several plant pathogenic fungi and bacteria (Jindal et al., 1988, Aly et al., 2002 and Esh et al., 2010). Different microorganisms were select as an bioagents against $A$. solani, i.e. Cladosporium herbarum, Aspergillus spp., Penicillium spp., Acremonium strictum, A. alternate, Ulocladium botrytis and Scopulariopsis brevicaulis (Ahmed and Saleh, 1991), T. harzianum (ElFarnawany, 2006 and Ahmed, Amal, 2009), Pseudomonas sp.(Casida and Lukezic (1993), Bacillus megaterium, B. brevis and B. subtilis var globigii (Liu and Wu 1997) and Streptomyces pulcher (El-Abyad et al., 1993).

The modern plant protection system has involved the new means that act not directly on the pathogen, but activate the natural defence mechanisms of the plant and enhance the same physiological and biochemical changes in plants as does the biological systemic activated resistance (Surviliene et al. 2003). Systemic acquired resistance (SAR) can be induced in various plants by different biotic agent (VanLoon et al., 1997 and Aly et al., 2002) and by chemical inducers such as DI-B-aminobutyric acid (Suli et al., 2002; Atia et al., 2003, Atia, 2005), bion (Atia, 2000), chitosan (Benhamou et al. 1998 and Atia, et al., 2005) and salicylic acid (Atia, et al., 2003 and Liao, et al., 2003).

Salicylic acid (SA) is an importants singnal molecule that plays a critical role in plant defence against pathogen invasion (Chaturvedi and Shah, 2007). Liao et al. (2003) found that, resistance in tomato plants to early blight caused by $A$. solani was induced by chitosan $(1 \mathrm{mg} / \mathrm{ml})$ at the four leaf stage of seedlings and activate its defense mechanisms. Atia (2005), found that, melon plants treated with DI-B-amino-n-butyric acid (BABA) $(10 \mathrm{mM}) 7$ days before inoculation with $A$. cucumerina resulted in significant disease protection locally and systemically. Treating tomato plants with chitosan $(1 \mathrm{mg}$ $\mathrm{ml}^{-1}$ ) 7 days before inoculation with Phytophthora infestans resulted in significant disease protection (Atia el al., 2005).

Essential plant extract and oils has been used to control several plant diseases on various crops (Hafez, 2008 and Fawzi et al., 2009). Ashrafuzzaman et al., (1990) mentioned that plant extracts of medicinal species play an important role in controlling the early blight pathogen in vitro and vivo. Generally, garlic extract was the best extract used tomato early blight disease. Suwitchayanon and Kunasakdakul, (2009) found that, clove extract was very effective in controlling A. cucumerina on melon.

Thus, this work aimed to investigate the antagonistic activities of different microorganisms, induced resistance by the selected chemical inducers, anti-fungal activity of some plant extracts on mycelia growth, spores germination and infection with Alternaria solani the causal of early blight disease of tomato under greenhouse conditions.

\section{MATERIALS AND METHODS}

Sourse of isolate: $A$. solani isolate used during this investigation was isolated and its pathogeneicity was confirmed (Ahmed, Amal, et al., 2009), detached and/or intact leaf techniques were used during this study (Atia et al. 2005 and Reni et al. 2007). 
Sourse of bioagents: Tomato leaf surface microflora was isolated, purified using dilliution method. Bacteria were isolated using King's B medium (King, et al. 1945). Actinomycetes were isolated on Jensens agar medium (Jensen, 1930). Identification of fungal bacteria and actinomycetes were identified according to their shape, pigmentation and culture characteristics based on Berge's Manual of Determinative Bacteriology $9^{\text {th }}$ ed. (Holt et al., 1994). Trichoderma spp., Bacillus subtilus and Pseudomonas flouescense bioagents tested were obtained from PI. Path. Laboratory, Agric. Bot. \& PI. Path. Dept., Fac. Agric., Zagazig Univ.

Tomato plants: tomato Gs cv. seedlingsand/or plants were transplanted in plastic pots $(30 \mathrm{~cm}$. in diameter) filled with a soil mixture, pots were kept under greenhouse conditions at Agric. Bot. \& PI. Path. Dept. Fac. Agric. Zagazig Univ. Plants at 4-5 weeks old, with 5-6 full true leaves were used Inoculum preparation: inoculum of $A$. solani isolate was prepared from cultures grown on PDA medium for 7 days at $28 \pm 2^{\circ} \mathrm{C}$. Mycelial mats were washed several times with sterilized distilled water, then blended with water for $3 \mathrm{~min}$. Then fungal suspension concentration was adjusted microscopically with aid of the hemocytometer technique to $10^{5} \mathrm{cfu} / \mathrm{ml}$ (Brame and Flood 1983).

\section{Biological control}

In vitro assay

The interaction between different isolated microorganisms i.e. bacteria (Bacillus subtilus, Pseudomonas flouescense, A and B isolates); actinomycetes ( $\mathrm{A}$ and $\mathrm{B}$ isolates) and fungi (Trichoderma spp.) and $A$. solani growth isolate was tested. Petri dishes $(9 \mathrm{~cm}$ in diameter) containing PDA medium were inoculated in the center with disk ( $5 \mathrm{~mm}$ in diameter) taken from the edges of 7 days old $A$. solani. Inoculation with the tested isolated bacteria and actinomycetes were done by streaking on the surface of the media at the distance of $1.5 \mathrm{~cm}$ from the edge of the plates with aid of dual culture method. While in case of fungi, plates were inoculated with agar disks ( $5 \mathrm{~mm}$ in diameter) of the tested fungi at the distance of $1.5 \mathrm{~cm}$ from the edge of the plates. Plates inoculated with $A$. solani alone were used as a control. Then plates were incubated at $28 \pm 2^{\circ} \mathrm{C}$. Three plates were used for each treatment. When the plates of control were covered with the mycelial growth of $A$. solani (7-10 days later) the mean diameter of the mycelial growth of different treatments was measured. The percentage of growth was calculated using the following formula: $A / B \times 100$.

$A=$ the mean diameter of the growth in the treatment.

$B=$ the mean diameter of the growth in the control.

In vivo assay:

Detached leaf technique:

Effect of the most antagonistic fungi, bacteria and actinomycetes on the infection with $A$. solani using detached leaf technique was carred out. Fungal isolates (Trichoderma spp.) were grown on $200 \mathrm{ml}$ of sterilized potato dextrose broth medium in $500 \mathrm{ml}$ Erlenmeyer flasks on a rotary shaker (100 rpm) for 7 days at $28 \pm 2^{\circ} \mathrm{C}$. (Aly et al., 2002). The liquid culture were mixed in a blender and adjusted to contain $10^{6} \mathrm{cfu} / \mathrm{ml}$. Bacterial and actinomycetes 
isolates were grown on King's B liquid medium (King et al., 1945). Flasks $(500 \mathrm{ml})$ each containing $100 \mathrm{ml}$ of King's B medium were inoculated with a lop full of $24 \mathrm{~h}$ old of bacteria and/or actinomycetes cultures. Flasks were incubated at $28^{\circ} \mathrm{C}$ on rotary shaker $(100 \mathrm{rpm}$ ) for $24 \mathrm{~h}$ in case of bacterial (Aly et al., 2002) and 9 days in case of actinomycetes (Lotfy, Maisa, 1996).

Tomato plants were sprayed with $30 \mathrm{ml} /$ plant of each tested organism suspension alone, control treatment was sprayed with autoclaved potato broth dextrose and or King's B media. Then all treated plants were covered with plastic box under greenhouse conditions. After 2 and 7 days detached leaves were transferred into $15 \mathrm{~cm}$. $\varnothing$ Petri dishes with moisten filter papers. Three Petri-dishes were used as a replicates for each concentration. The lower surface of treated leaflets was inoculated with 6 drops $(30 \mu \mathrm{l}) / /$ leaflet of $10^{5} \mathrm{cfu}$ of $A$. solani isolate. Inoculated leaflets were incubated at $23^{\circ} \mathrm{C}$ and the disease incidence was calculated after 7-10 days. Number and diameter of necrotic lesions $(\mathrm{mm})$ as well as blighted area $\left(\mathrm{mm}^{2}\right) /$ leaflet were determined. Percentage of protection was calculated as follows:

Percentage of protection $=100-\mathrm{A} / \mathrm{B}$

$A=$ Percentage of disease in treated $(100 \times$ blighted area in treated/ blighted area in the untreated (control).

$B=$ percentage of disease in untreated (control) mentioned before.

Intact leaves:

Effect of the antagonistic microorganisms on early blight disease was also studied under greenhouse conditions on intact leaves. The inoculum of the tested organisms was prepared as mentioned before. Tomato plants (4-5 weeks old) were sprayed with $30 \mathrm{ml} /$ plant of each tested organism suspension alone, and the control treatment was done. Three replicates for each particular treatment were used. The sprayed plants were covered with plastic box under greenhouse conditions. After 2 and 7 days after spraying, plants (intact leaves) were sprayed with $30 \mathrm{ml} / \mathrm{plant}$ of $10^{5} \mathrm{cfu} / \mathrm{ml}$ of $A$. solani. Inoculated plants were incubated under plastic box under greenhouse conditions for 48 days. Infection with $A$. solani and disease assessment was determined using 1-9 scale (Pandey et al. 2003).

Induced resistance:

These experiments aimed to study the effect of some inducers on enhance disese resistance in tomato plants to early blight pathogen $A$. solani as well as dirct antifungal activity on linear growth and spore germination under in vitro conditions were also tested.

\section{In vitro assay:}

\section{Effect of different concentrations of chitosan and salicylic acid on linear} growth of $A$. solani:

Different concentrations $(0,1,2$ and $4 \mathrm{~g} / \mathrm{l})$ of chitosan and salicylic acid (SA) were tested on the linear growth of $A$. solani using PDA medium. Purified chitosan solution (Sigma Chemical Company) was prepared using methods similar to those of El-Ghaouth et al. (1994) and Atia et al., (2005) and $\mathrm{pH}$ was adjusted to 6.5 with $0.5 \mathrm{NaOH}$ (Benhamou et al., 1998). One drop $(10 \mu \mathrm{l})$ of each chitosan solution was placed onto the surface of PDA in each of five Petri dishes. A mycelial disc was then placed facing downwards 
onto the chitosan droplet. Sterile water and $\mathrm{pH}$ was adjusted to 6.5 with $\mathrm{HCl}$ $(0.25 \mathrm{~N})$ solution were used as a control (to check whether it had any effect on pathogen growth or not).

Different SA concentrations $(0.1,0.2,0.5,1,2$ and $4 \mathrm{~g} / \mathrm{l})$ were incorporated in $100 \mathrm{ml}$ PDA media and poured in $9 \mathrm{~cm}$ Petri dishes. A $5 \mathrm{~mm}$ diameter agar disc containing fungal mycelium growth was transferred to the test medium. Three plates for each concentration were used, and control one was also done. Then plates were incubated at $28 \pm 2^{\circ} \mathrm{C}$. Colony diameters were measured when the surface of control in Petri dishes was covered with the fungal growth.

Effect of different concentrations chitosan and salicylic acid on spore germination of $\boldsymbol{A}$. solani:

The effect of different concentrations of chitosan and SA was studied using the slide technique described by Nair and Ellingboe (1962). A drop of each inducer concentration alone was deposited on dried clean glass slide as a film. A drop of spore suspension of $A$. solani $10^{5} \mathrm{cfu} / \mathrm{ml}$ was spread over this film. Control treatment was prepared using sterilized distilled water. Three replicates were used for each concentration. Slides were placed on ushap glass rod in Petri-dish under moisten conditions and incubated for $24 \mathrm{~h}$ at $28 \pm 2^{\circ} \mathrm{C}$. Spores germination (\%) was calculated.

\section{In vivo assay:}

Effect of different chitosan and salicylic acid concentrations on disease incidence using detached leaf technique:

Different concentrations of chitosan (1,2 and $4 \mathrm{~g} / \mathrm{l})$ and SA (0.1, 0.2 , $0.5,1,2$ and $4 \mathrm{~g} / \mathrm{l}$ ) were tested against early blight on tomato Gs cv. detached leaves. The tested concentrations were sprayed on the upper and lower surface of leaves. Then, sprayed tomato leaves were detached 7 days after treatment. Detached leaves were removed immediately before inoculation and then placed in Petri-dishes $(15 \mathrm{~cm} \varnothing)$ containing filter paper saturated with sterilized water. Detached leaves were inoculated with 6 drops (30 $\mu \mathrm{l}) /$ leaflet $A$. solani and/or water as a control. Three replicates were used for each concentration. Inoculation and disease incidence were done as mentioned before.

Intact leaves:

Effect of different concentrations of chitosan and SA on early blight disease incidence under greenhouse conditions:

Different concentrations of chitosan (1,2 and $4 \%)$ and SA $(0.4,0.6$, $0.8,1.0 \mathrm{mM}$ ) were tested against tomato early blight using detached leaves of Gs cv. Tomato plants at 4-5 weeks old were sprayed with the inducer concentrations. After 7 days treated plants were inoculated with spore suspension of $A$. solani $10^{5} \mathrm{cfu} / \mathrm{ml}$. Inoulation with $A$. solani and disease assessment were carried out as mentioned before.

Plant extracts:

This experiment was conducted to study the effect of eight plant extracts illustrated in Table (1) with different methods of extraction (cold water and ethanol) on growth, spore germination of $A$. solani, as well as on infection 
with late blight pathogen using detached leaf technique and/or intact leaves under greenhouse conditions.

Preparations of plant extracts:

Plant materials were collected separately, and then washed thoroughly with distilled water then transferred and left to dry at room temperature. Solvents (water and ethanol) were added at 1:1 (V/W). The juice of frizzed cloves of garlic was obtained by crushing them in blender for five min., and then filtrated through two layers of cheesecloth.

Fifty grams of green leaves of sweet basil, banyan tree and henna as well as herb of thyme, sweet marjoram, and rhizome of ginger were crushed with $50 \mathrm{ml}$ of distilled water in a blender for 5 minutes. The filtered extract was centrifuged at $3000 \mathrm{rpm}$, for 15 minutes and sterilized using Zeits filter. The sterilized crude extract was considered as representative to $100 \%$ concentration, and serial dilutions (i.e.100, 50, 20, 10, 5 and 2\%) were prepared using sterilized distilled water.

Table (1): List of tested plant extracts.

\begin{tabular}{lccc}
\hline English name & Scientific name & Family & The plant parts used \\
\hline Garlic & Allium sativum L. & Liliaceae & Cloves \\
Banyan tree & Ficus nitida L. & Moraceae & Leaves \\
Henna & Lowsonia inermis L. & Lythraceae & leaves \\
Thyme & Thymus vulgaris L. & Labiatae & Herb \\
Sweet basil & Ocimum basilicum L. & Labiatae & Leaves \\
Sweet majoram & Origanum majorana L. & Labiatae & Herb \\
Ginger & Zingiber officnalis L. & ingiberaceae & Rhizome \\
\hline
\end{tabular}

For extraction by ethanol, fifty grams of green leaves, herbs and rhizome were crushed with $50 \mathrm{ml}$ of ethanol $95 \%$ in a blender for 5 minutes and then stored in refrigerator for $24 \mathrm{~h}$. filtration; centrifugation and sterilization were done as mentioned before. Supernatant was collected in $250 \mathrm{ml}$ flask and incubated at $60^{\circ} \mathrm{C}$ in water bath to allow solvents evaporation till flasks contents become powder film, then flasks removed and dried residues were re-dissolved in $50 \mathrm{ml}$ of distilled water. The crude extract was considered as representative to $100 \%$ concentration, and serial dilutions (from 100 to $5 \%$ ) were made using sterile distilled water.

\section{Effect of different concentrations of plant extracts on the linear growth} of $A$. solani under in vitro conditions:

Different concentrations of each extract ( 0 concentration used as a control, 2, 5, 10, 20, 50 and $100 \%$ of the crude extracts) $5 \mathrm{ml}$ from each of the concentrations was dispensed into $9 \mathrm{~cm}$ diameter Petri dishes after which 20 $\mathrm{ml}$ of melted PDA medium were poured into the plate, then shaken together and allowed to solidify. Three plates for each concentration were used and inoculated at the center with equal discs $(5 \mathrm{~mm}$ in diameter) taken from 7 days old culture of $A$. solani. Then plates were incubated at $28 \pm 2^{\circ} \mathrm{C}$ until mycelial growth of pathogen covered the surface of medium in control treatment (Qasem and Abu-Blan, 1996). The antifungal activity of plant extract was calculated and measured as percentage reduction of growth of pathogen comparing with control using this formula: 
Linear growth reduction (\%):

$$
=\frac{\text { Growth in control }- \text { Growth in treatment }}{\text { Growth in control }} \times 100
$$

\section{Effect of plant extracts on spore germination of $A$. solani:}

The most effective plant extracts on mycelia growth of $A$. solani were tested on spores germination. Plant extracts were prepared as mentioned before, Antifungal activity of plant extracts on spores germination of $A$. solani was tested using the slide technique method reported by Nair and Ellingaboe (1962) and El-Nagger (1997).

\section{Effect of plant extracts on disease incidence using detached leaf technique:}

Tomato leaves (leaf number 2 and 3 ) were sprayed with different concentrations $(10,20,50,100 \%)$ of garlic and ginger, the most effective plant extracts on mycelia growth and spores germination of $A$. solani. One day after treatment, leaves of sprayed tomato plants were detached and transferred into Petri-dishes $(15 \mathrm{~cm}$ in diameter) containing filter paper saturated with $10 \mathrm{ml}$. of sterilized water. Inoculation, incubation and disease parameter were done as mentioned before.

In addition, tomato detached leaves were inoculated with a mixture of the aforementioned concentration and fungal spore suspension $(1: 1 \mathrm{v} / \mathrm{v})$ to test the direct effect on the disease incidence at the same time.

Effect of plant extracts on disease incidence using intact leaves:

Tomato Gs cv. 4-5 weeks old seedlings were sprayed with the plant extracts. After $24 \mathrm{~h}$. plants were sprayed with $A$. solani as mentioned above. Plants sprayed with distilled water served as a control. Sprayed plants were covered with plastic box under greenhouse conditions. Incubation and disease parameter were done as mentioned before.

Statistical analysis:

Data were statistically analyzed by analysis of variance according to Snedecor and Cochron, (1982) using SPSS system version 8, (1997).

\section{RESULTS AND DISCUSSION}

All tested fungal isolates were effective on reducing growth of $A$. solani the causal organism of early blight disease. Results also indicated that, Trichoderma viride was the most effective which completely (100\%) reduced A. solani mycelial growth, followed by $T$. harizianum (88.32\%), actionmycetes A $(70.56 \%)$ and Bacillus subtilus (63.33\%) followed by bacteria A (56.04), bacteria B (52.10\%) and bacteria A (56.04\%) and finally Pseudomonas florcense $(42.22 \%)$, Table (2). T. viride and $T$. harizanum were the most effective species resulting a sharply reduction in the pathogenic fungal growth comparatively with the others teste microorganisms. This high potentiality in antagonism might be due to $T$. viride acts through the lack of substrate effect on mycelium dray weight, also with different pectin substrates (Metha et al., 1975). Trichoderma spp. are prolific producers of extra cellular proteins, and are best known for their ability to produce enzymes. (Harman and Kubicek 1998). Hyphal interaction between the bio-agent $T$. harzianum and $A$. solani 
occurred by different means such as growing in contact, complete colonization and coiling around the hyphae of the pathogen, direct penetration and formation of appressorium-like structures. The interaction between $T$. harzianum and conidia of $A$. solani resulted in malformations and changes in spore shape, growing in contact and attaching spores and formation of node-like structure between two successive conidia (ElFarnawany 2006).

Table (2): Effect of different bio-agents on growth reduction (\%) of Alternaria solani.

\begin{tabular}{lc}
\hline \multicolumn{1}{c}{ Bio-agents } & Growth reduction (\%) \\
\hline Actionmycetes (Streptomyces sp.) A & 70.56 \\
Actinomycetes (Streptomyces sp.) B & 40.37 \\
Bacillus subtilus & 63.33 \\
Bacteria (Bacillus sp.) A & 56.04 \\
Bacteria (Bacillus sp.) B & 52.10 \\
Pseudomonas florcense & 42.22 \\
Trichoderma viride & 100.00 \\
Trichoderma harizianum & 88.32 \\
Control & 0.00 \\
\hline L.S.D at 5\% & 3.12 \\
\hline
\end{tabular}

B. subtilius isolates were used against several diseases i.e. CLS of sugar beet (Taghian, Shadia et al. 2008 and Esh et al., 2011); cucurbit powdery mildew (Gilardi, et al., 2008) and gray mould of strawberries (Ju, et al., 2007). Several bacterial genera have been successfully used for the biological control (Aly et al., 2002 and, Yusran, et al., 2008). On the other hand, actenomycetes are known to produce one or more antibacterial, antifungal, antiviral, anti-protozoal, (Holt et. al. 1994). Streptomyces longisporus, isolated from field soil, showed in vitro antagonism against $A$. solani. It produced antifungal activity compounds, such as guanidyl, nigericin and geldanamycin. It also, produced hydrolytic enzymes i.e. chitinase and $\beta-1,3-$ gluconase (Trejo et al. 1998).

Data in Table (3) indicate that, $T$. harizanum inculcated 2 days before pathogen application was the most effective one on reducing mean number of lesion, diameter of lesion $(\mathrm{mm})$, infected area $\left(\mathrm{mm}^{2}\right)$ and protection (\%), which gave $2.25,1.96 \mathrm{~mm}, 9.09 \mathrm{~mm}^{2}$ and $96.57 \%$ respectively, followed by $T$. viride $\left(3.75,2.53 \mathrm{~mm}, 19.00 \mathrm{~mm}^{2}\right.$ and $92.65 \%$ then $B$. subtilus $(4,3.72 \mathrm{~mm}$, $43.64 \mathrm{~mm}^{2}$ and $83.34 \%$ ), respectively, compaed to the control. The same trends were obtained one week before inoculation, (Table, 3). Wherase, $T$. harizanum was the most effective one $\left(3.33,2.9 \mathrm{~mm}, 21.86 \mathrm{~mm}^{2}\right.$ and $\left.89.84 \%\right)$ followed by $T$. viride $\left(4,3.33 \mathrm{~mm}, 34.92 \mathrm{~mm}^{2}\right.$ and $83.77 \%$ respectively), then B. subtilus $\left(5,4.26 \mathrm{~mm}, 71.23 \mathrm{~mm}^{2}\right.$ and $66.89 \%$ respectively), compaed to the control $(6,6.77,216.99$ and 0$)$.

$T$. harizanum was the most effective bioagent in controlling tomato early blight which reduced disease severity and percentage of infection (16.44 \% and $58.62 \%$ ) followed by B. subtilius ( $20.56 \%$ and $64.44 \%$ ) then T. viride $(27.12 \%$ and $68.91 \%)$ two days before inoculation with the pathogen. While, actinomycets-A was the lowest effective one (35.53\% and $76.00 \%)$, 
compaed to the control. Results e also indicat that, $T$. harizanum was the most effective one causing a reduction in disease severity $(70.18 \%)$ and reduction percentage of infection (38.28\%), followed by $B$. subtilius $(62.65 \%$ and $31.53 \%)$ and $T$. viride (50.75\% and $26.8 \%)$. While, Actinomycets-A was the lowest effective one (35.51\% and $19.25 \%)$, compaed to the control.

Table (3): Effect of different bio-agents on tomato early blight disease incidence using detached leaf technique two and seven days after spraying bio-agents.

\begin{tabular}{|c|c|c|c|c|c|}
\hline The tested bio-agents & Time & $\begin{array}{l}\text { Number of } \\
\text { lesions }\end{array}$ & $\begin{array}{l}\text { Diameter of } \\
\text { lesion (mm) }\end{array}$ & $\begin{array}{c}\text { Infected } \\
\text { area }\left(\mathrm{mm}^{2}\right)\end{array}$ & $\begin{array}{l}\text { Protection } \\
(\%)\end{array}$ \\
\hline $\begin{array}{l}\text { Actinomycets A } \\
\text { Bacillus subtilus } \\
\text { Trichoderma viride } \\
\text { Trichoderma harizanum } \\
\text { Control } \\
\text { Mean } \\
\end{array}$ & 2 days & $\begin{array}{l}4.20 \\
4.00 \\
3.75 \\
2.25 \\
6.00 \\
\mathbf{4 . 0 4} \\
\end{array}$ & $\begin{array}{l}4.08 \\
3.72 \\
2.53 \\
1.96 \\
7.06 \\
\mathbf{3 . 8 7} \\
\end{array}$ & $\begin{array}{c}56.72 \\
43.64 \\
19.00 \\
9.09 \\
264.94 \\
78.68 \\
\end{array}$ & $\begin{array}{c}78.40 \\
83.34 \\
92.65 \\
96.57 \\
0.00 \\
\mathbf{7 0 . 1 9} \\
\end{array}$ \\
\hline L.S.D at $5 \%$ & & 0.34 & 0.39 & 27.33 & 2.65 \\
\hline $\begin{array}{l}\text { Bacillus subtilus } \\
\text { Trichoderma viride } \\
\text { Trichoderma harizanum } \\
\text { Control } \\
\text { Mean }\end{array}$ & 7 days & $\begin{array}{l}5.00 \\
4.00 \\
3.33 \\
6.00 \\
4.58\end{array}$ & $\begin{array}{l}4.26 \\
3.33 \\
2.90 \\
6.77 \\
3.32\end{array}$ & $\begin{array}{l}71.23 \\
34.92 \\
21.86 \\
216.99 \\
\mathbf{8 6 . 2 5}\end{array}$ & $\begin{array}{l}66.89 \\
83.77 \\
89.84 \\
0.00 \\
60.13\end{array}$ \\
\hline L.S.D at $5 \%$ & & 0.37 & 0.70 & 21.55 & 3.64 \\
\hline
\end{tabular}

$T$. harizanum was the most effective one in controlling the disease severity and percentage of infection $(22.26 \%$ and $62.43 \%)$ followed by $B$. subtilius (28.25 and $69.70 \%)$, then, T. viride (35.56\% and $73.85 \%)$ Table, 4. Results also indicate that, $T$. harizanum was the most effective on reducing disease severity $(61.84 \%)$ and percentage the infection $(35.17 \%)$, followed by B. subtilius $(51.52 \%$ and $27.62 \%)$, then, T. viride $(39.03 \%$ and $23.32 \%)$, compared to the control. Under greenhouse conditions $T$. harizanum controlled tomato early blight 2 , and 7 days after application.

Table (4): Effect of different bioagent application on tomato early blight disease incidence under greenhouse conditions, two days spraying bioagent on intact leaf.

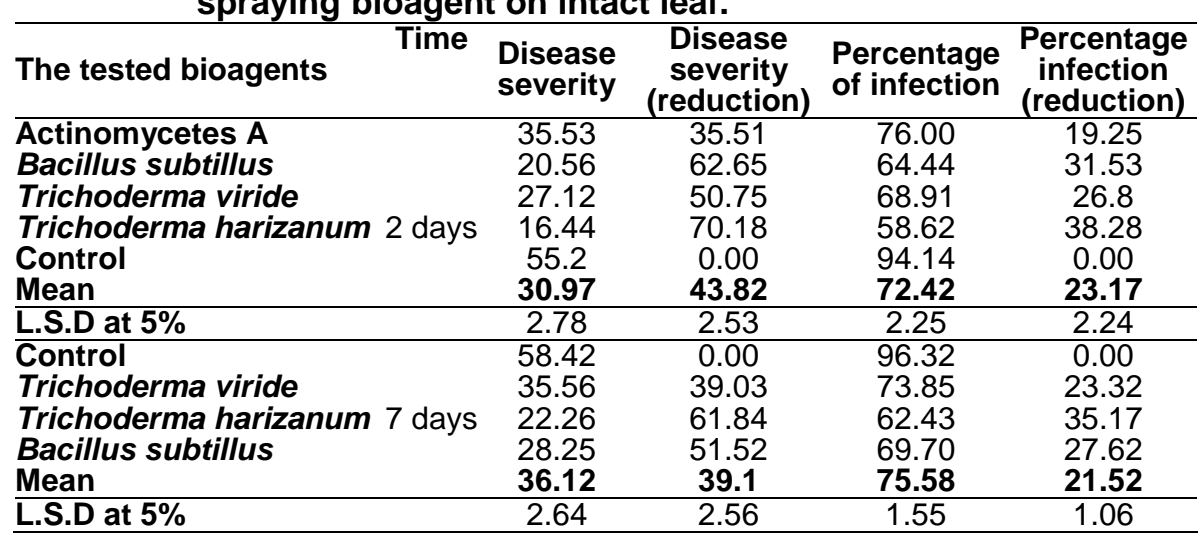


This effect might be due to induce anti-fungal or layatic compounds (Yahia et al., 1990) in its culture or mycoparasitism (Handlesman and Park 1989). T. harizanum attached host and can coil around it and forming appressoria on the host surface. Attachment is mediated by the binding of carbohydrates in the Trichoderma cell wall to lectins on target fungus (Inbar et al., 1998). Once in contact, Trichoderma spp. produced several fungitoxic cell-wall degrading enzymes (Chet et al., 1998), and probably also peptaibol antibiotics (Schirmböck et al., 1994). The combined activities of these compounds resulted in parasitism of target fungus, and dissolution its cell walls. At the sites of the appressoria, holes can be produced in the target fungus, and direct entry of Trichoderma hyphae into the lumen of the target fungus occurs. There are at least 20-30 known genes, proteins and other metabolites that are directly involved in this interaction, which is typical of the complex systems that are used by these fungi in their interactions with other organisms.

Data in Table (5) show that, all tested concentrations of chitosan and SA reduced the linear growth of $A$. solani on agar plates compared to the control. Concentration $4 \mathrm{~g} / \mathrm{l}$ of both tested inducers was the most effective (84.44 and $67.77 \%$ ), followed by $2 \mathrm{~g} / \mathrm{l}$ (78.8 and 56.84), then $1 \mathrm{~g} / \mathrm{l}$ (73.7 and 44.44). Chitosan was the most effective than SA on reducing mycelial growth. The reduction effect was increased with increasing concentrations of both inducers. The same trends were obtained in case of spore germination (Table, 5). Concentration $4 \mathrm{~g} / \mathrm{l}$ of chitosan and $\mathrm{SA}$ reveald the hightest reduction percentage of spore germination ( 55.31 and 81.56 ) followed by $2 \mathrm{~g} / \mathrm{l}$ (42.09 and 76.18), then $1 \mathrm{~g} / \mathrm{l}(28.39$ and 65.61) of chitosan and SA respectively. it is also clear that, SA was most effective than chitosan on reducing spore germination of $A$ solani. Increasing concentration of both chitosan and SA resulted in reducing spore germination percentage.

Table (5): Effect of different concentrations of salicylic acid and chitosan on growth reduction and spores germination (\%) of Alternaria solani.

\begin{tabular}{cccc}
\hline $\begin{array}{c}\text { Chemical } \\
\text { inducers }\end{array}$ & $\begin{array}{c}\text { Concentration } \\
(\mathbf{g} / \mathbf{l})\end{array}$ & $\begin{array}{c}\text { Growth } \\
\text { (reduction\%) }\end{array}$ & $\begin{array}{c}\text { Linear } \\
\text { Spores germination } \\
\text { (reduction \%) }\end{array}$ \\
\hline \multirow{4}{*}{ Chitosan } & $\mathbf{0 . 0}$ & 0.00 & 0.00 \\
& $\mathbf{1 . 0}$ & 73.70 & 28.39 \\
& $\mathbf{2 . 0}$ & 78.80 & 42.09 \\
& $\mathbf{4 . 0}$ & 84.44 & 55.31 \\
& Mean & $\mathbf{5 9 . 2 6}$ & $\mathbf{3 1 . 4 5 9}$ \\
& $\mathbf{0 . 0}$ & 0.00 & 0.00 \\
Salicylic acid & $\mathbf{0 . 1}$ & 13.68 & 25.56 \\
& $\mathbf{0 . 2}$ & 21.08 & 35.40 \\
& $\mathbf{0 . 5}$ & 34.42 & 56.26 \\
& $\mathbf{1 . 0}$ & 44.44 & 65.61 \\
& $\mathbf{2 . 0}$ & 56.84 & 76.18 \\
& $\mathbf{4 . 0}$ & 67.77 & 81.56 \\
\hline & Mean & $\mathbf{2 4 . 3 5}$ & $\mathbf{3 7 . 0 0}$ \\
\hline
\end{tabular}


The inducer concentrations tested decreased number of lesion; diameter of lesion, blighted area and protection (\%) of tomato leaves Gs cv. (Table, 6). It is also clear that, increasing the concentrations of chitosan and/or SA lead to decrease the disease incidence and increase protection $(\%)$. The highest concentration $(4 \mathrm{~g} / \mathrm{l})$ of chitosan and SA was the most effective on reducing disease number of lesion (3.25 and 2) and diameter of lesion (3.48 and 1.26), infected area (31.29 and 2.5) and protection\% (88.56 and $99.09 \%)$ respectively. Followed by $2 \mathrm{~g} / \mathrm{l}$ [(4.5, and 2$),(4.66$, and 1.94$)$, (76.84 and 9.09) and (71.99 and 96.68) of chitosan and SA respectively], then $1 \%$ compared to control one $(6,7.63,274.44$ and $0 \%)$. Data also indicated that SA was most effective than chitosan on tomato early blight disease.

Table (6): Effect of application different concentrations of selected chemical inducers on tomato early blight disease incidence using detached leaf technique.

\begin{tabular}{|c|c|c|c|c|c|}
\hline $\begin{array}{l}\text { Chemical } \\
\text { inducers }\end{array}$ & $\begin{array}{c}\text { Concentration } \\
(\mathrm{g} / \mathrm{l})\end{array}$ & $\begin{array}{c}\text { Number } 0 \\
\text { lesions }\end{array}$ & $\begin{array}{l}\text { f Diameter of } \\
\text { lesion }(\mathrm{mm})\end{array}$ & $\begin{array}{c}\text { Infected } \\
\text { area }\left(\mathrm{mm}^{2}\right)\end{array}$ & $\begin{array}{l}\text { Protection } \\
(\%)\end{array}$ \\
\hline \multirow{4}{*}{ Chitosan } & 0.0 & 6.00 & 7.63 & 274.44 & 0.00 \\
\hline & 1.0 & 5.33 & 5.16 & 112.69 & 58.91 \\
\hline & 2.0 & 4.50 & 4.66 & 76.84 & 71.99 \\
\hline & 4.0 & 3.25 & 3.48 & 31.29 & 88.56 \\
\hline \multirow{7}{*}{ Salicylic acid } & Mean & 4.77 & 5.23 & 123.82 & 54.87 \\
\hline & 0.0 & 6.00 & 7.63 & 274.44 & 0.00 \\
\hline & 0.5 & 4.16 & 3.83 & 48.27 & 82.40 \\
\hline & 1.0 & 3.50 & 2.60 & 18.76 & 93.16 \\
\hline & 2.0 & 3.00 & 1.94 & 9.09 & 96.68 \\
\hline & 4.0 & 2.00 & 1.26 & 2.5 & 99.09 \\
\hline & Mean & 3.73 & 3.45 & 70.61 & 74.27 \\
\hline \multicolumn{2}{|c|}{ L.S.D at $5 \%$} & 0.55 & 0.37 & 15.77 & 19.00 \\
\hline
\end{tabular}

Data present in Table (7) reveal that, all tested concentrations of chitosan and SA induced diseased resistance and decreased disease severity and percentage of disease incidence. Also, disease severity and percentage of disease incidence decreased with increasing concentrations of chitosan and SA. Data also indicated that, the highest concentrations $(4 \mathrm{~g} / \mathrm{l})$ of chitosan and SA were the most effective one in inducing disease resistance, reducing disease severity and percentage of infection (30.32 and 69.64 in case of chitosan and 11.03 and 49.99 in case of SA respectively), then $2 \mathrm{~g} / \mathrm{l}$. The lowest effective in inducing resistance to tomato early blight disease compared to the control (56.52 and 95.75). Simillar results were obtained by (Atia et. al., 2003 and 2005, Liao, et. al. 2003).

The inhibition effect of tested inducers (chitosan and SA) on the growth of the causal organism of tomato early blight disease and disease assessment were agreement with the results obtained by Bahaskara et al., (2000) and Atia et al., (2003 and 2005). The anti-fungal activities due to 2hydroxy-5-nitrobenzylideneamino and 5-chloro-2-hydroxybenzylideneamino group. As antifungal groups, the nitro and chloro groups are used in many fungicides such as pentachloronitrobenzene (PCNB) and chlorothalonil. But 
these fungicides have pronounced toxicities and their residues in the environment have been developing as serious problems. When these groups are grafted onto chitosan, they should be released slowly and might meet the requirements of environmental safety (Zhanyong et al. 2006).

Table (7): Effect of application different concentrations of selected chemical inducers on early blight disease incidence using intact leaves.

\begin{tabular}{|c|c|c|c|c|c|}
\hline $\begin{array}{l}\text { Chemical } \\
\text { inducers }\end{array}$ & $\begin{array}{c}\text { Concentration } \\
(\mathrm{g} / \mathrm{l})\end{array}$ & $\begin{array}{l}\text { Disease } \\
\text { severity }\end{array}$ & $\begin{array}{c}\text { Reduction } \\
\text { of disease } \\
\text { severity }\end{array}$ & $\begin{array}{l}\text { Percentage } \\
\text { of infection }\end{array}$ & $\begin{array}{l}\text { Reduction of } \\
\text { percentage } \\
\text { infection }\end{array}$ \\
\hline \multirow[t]{7}{*}{ Chitosan } & 0.0 & 56.52 & 0.00 & 95.75 & 0.00 \\
\hline & 1.0 & 47.39 & 16.15 & 81.03 & 15.36 \\
\hline & 2.0 & 39.83 & 29.49 & 75.56 & 21.08 \\
\hline & 4.0 & 30.32 & 46.34 & 69.64 & 27.28 \\
\hline & Mean & 43.52 & 23.00 & 80.50 & 15.93 \\
\hline & 0.0 & 56.52 & 0.00 & 95.75 & 0.00 \\
\hline & 0.5 & 34.14 & 39.88 & 69.72 & 27.17 \\
\hline \multirow[t]{4}{*}{ Salicylic acid } & 1.0 & 26.83 & 52.44 & 64.35 & 32.77 \\
\hline & 2.0 & 18.79 & 66.74 & 55.72 & 41.79 \\
\hline & 4.0 & 11.03 & 80.48 & 49.99 & 47.78 \\
\hline & Mean & 29.46 & 47.91 & 67.11 & 29.90 \\
\hline \multicolumn{2}{|c|}{ L.S.D at $5 \%$} & 2.55 & 2.85 & 6.35 & 1.51 \\
\hline
\end{tabular}

Chitosan treatments increased the activities of peroxidase, polyphenol oxidase (catechol) oxidase, phenylalanine ammonia-lyase, chitinase and beta-1, 3-glucanase in the leaves but at various degrees depending on the cultivar (Liao et al. 2003 and Atia et al., 2005). The mode of action of chitosan is to stimulate natural defence response systems in treated plants. Poly-Dglucosamine binds to fungal receptor sites, mimicking an attack by fungal spores. This in turn results in signals being sent to the nuclei of the plant and triggering signals which elicit multiple genetic and biological responses, including the production of phytoalexins (anti-microbial compounds produced in plants, aimed at inhibiting infections (Peniston and Johnson. 1980).

SA played an important role in plant defense. Its rol in plant disease resistance is well documented for dicotyledonous plants, were it is required for basal resistance against pathogens as well as for the inducible defense mechanism of SAR, which confers resistance against a broad-spectrum of pathogens. The activation of SAR is associated with the heightened level of expression of the pathogenesis-related proteins (PRs), some of which possess antimicrobial activity (Atia et al., 2005 and Chaturvedi and Shah 2007). SA is an important endogenous molecule involved in plant defense. The link between SA production and SAR has been well established (Klessig and Malamy 1994). Transgenic plants expressing the salicylate dehydrogenase (nahG) gene, which converts SA into inactive catechol, do not establish SAR (Gaffney et al. 1993). Furthermore, there is a correlation between an increase in SA levels and plant gene expression. PR-proteins show up a few hours after the SA level begins to rise (Yalpani et al. 1993). 
Exogenous SA can induce simultaneous PR expression and resistance to pathogens, even in the absence of pathogenic organisms (Ward et al. 1991).

Table (8): Effect different water and ethanol plant extracts on mycelia growth reduction Alternaria solani.

\begin{tabular}{|c|c|c|c|c|c|c|c|c|c|}
\hline \multirow{2}{*}{ Plant extracts } & \multicolumn{9}{|c|}{ Concentration \% } \\
\hline & Extraction & 0 & 2 & 5 & 10 & 20 & 50 & 100 & Mean \\
\hline Garlic & method & 0.00 & 10.30 & 32.22 & 55.18 & 74.07 & 100 & 100 & 53.11 \\
\hline Banyan tree & & 0.00 & 9.99 & 22.59 & 27.38 & 32.22 & 38.20 & 53.70 & 26.29 \\
\hline enna & & 0.00 & 9.25 & 14.0 & 18.1 & 32.5 & 41.80 & 48.40 & 23.43 \\
\hline weet basil & Water & 32.59 & 29.60 & 28.45 & 26.99 & 23.70 & 22.22 & 16.99 & 25.79 \\
\hline majoram & extract. & 0.00 & 2.22 & 3.70 & 8.13 & 9.62 & 16.6 & 28.8 & 9.86 \\
\hline Thyme & & 0.00 & 0.00 & 0.00 & 1.48 & 10.74 & 13.33 & 25.16 & 7.24 \\
\hline Ginger & & 0.00 & 5.55 & 31.85 & 53.70 & 61.48 & 70.00 & 78.51 & 43.01 \\
\hline L.S.D at $5 \%$ & & 0.79 & 23.64 & 2.36 & 2.54 & 3.40 & 23.46 & 2.37 & \\
\hline Garlic & & 0.00 & 29.95 & 62.22 & 100 & 100 & 100 & 100 & 69.69 \\
\hline ginger & & 0.00 & 25.18 & 52.95 & 62.94 & 73.23 & 84.81 & 94.78 & 55.92 \\
\hline L.S.D at $5 \%$ & & 0.05 & 8.30 & 5.48 & 3.48 & 3.87 & 3.89 & 4.41 & \\
\hline
\end{tabular}

All tested concentrations $(0,2,5,10,20,50$ and $100 \%)$ of plant extracts decreased linear growth of $A$. solani compared with the control. Increasing concentration of any plant extract decreased the linear growth of the pathogen. Water extraction of garlic was the most effective on decreasing mycelial growth of $A$. solani $(53.11 \%)$ followed by ginger $(43.01 \%)$ while thyme was the lowest effective (7.24\%). On the other hand, sweet basil extracts increased growth of Alternaria solani (Table, 8). Both water and ethanol extracts of garlic were the most effective on inhibition spore germination of $A$. solani (62.01 and $72.20 \%$ ) followed by ginger extracted (45.59 and $50.79 \%)$. Increasing concentration decreased the percentage of germinated spores (Table, 9). These results were in agreement with those obtained by (Thiribhuvanamala et al. 2001). Several reports mentioned that the plant extracts play an important role in controlling the early blight pathogen in vitro and vivo (Ashrafuzzaman et al., 1990, Prasad and Naik 2003 and Satya et at., 2005).

Table (9): Effect different water and ethanol plant extracts on reduction of Alternaria solani spore germination.

\begin{tabular}{|c|c|c|c|c|c|c|c|}
\hline \multirow{2}{*}{ Plant extracts } & \multicolumn{6}{|c|}{ Spore germination (\%) } & \multirow[b]{2}{*}{ Mean } \\
\hline & 0 & 5 & 10 & 20 & 50 & 100 & \\
\hline Garlic & 0.00 & 57.96 & 66.80 & 71.32 & 87.08 & 100 & 62.01 \\
\hline ginger & 0.00 & 42.14 & 48.98 & 55.95 & 63.15 & 73.46 & 45.59 \\
\hline L.S.D at $5 \%$ & 1.45 & 4.89 & 7.98 & 6.35 & 6.31 & 4.83 & \\
\hline Garlic & 0.00 & 66.78 & 79.62 & 86.81 & 100 & 100 & 72.20 \\
\hline ginger & 0.00 & 43.87 & 50.73 & 60.49 & 69.88 & 79.80 & 50.79 \\
\hline L.S.D at $5 \%$ & 1.25 & 4.68 & 4.39 & 4.28 & 5.09 & 3.39 & \\
\hline
\end{tabular}

Using detached leaf technique, all plant extracts tested decreased number and diameter of lesion, infected area and increased protection (\%) of treated tomato leaves. Increasing concentrations of plant extract resulted in 
decreasing the mean number of lesions, diameter of lesion as well as infected area. Garlic extract was the most effective when used at the same time of inoculation on reducing mean number of lesion (1.21), diameter of lesion $(1.21 \mathrm{~mm})$, infected area $\left(34.36 \mathrm{~mm}^{2}\right)$ and protection \% $(79.98 \%)$ followed by ginger $\left(1.99 ; 1.90 \mathrm{~mm} ; 37.04 \mathrm{~mm}^{2}\right.$ and $\left.78.46 \%\right)$. In addition garlic was the most effective as spray application one day before inoculation with $A$. solani on reducing number of lesion (1.97); diameter of lesion $(1.56 \mathrm{~mm})$, infected area $\left(35.15 \mathrm{~mm}^{2}\right)$ and \% of protection $(79.53 \%)$ followed by ginger extract $\left(3.24 ; 3.07 \mathrm{~mm} ; 54.76 \mathrm{~mm}^{2}\right.$ and $\left.68.11 \%\right)$. Also, data indicated that, used plant extracts at the same time of inoculation with $A$. solani was better than when used one day before inoculation (Table, 10).

Table (10): Effect of plant extracts concentrations on tomato early blight disease incidence using detached leaf technique at different application times.

\begin{tabular}{|c|c|c|c|c|c|c|c|c|c|}
\hline \multirow[b]{2}{*}{$\begin{array}{l}\text { Plant } \\
\text { extracts }\end{array}$} & \multirow[b]{2}{*}{$\begin{array}{c}\text { Concentration } \\
\text { (\%) }\end{array}$} & \multicolumn{2}{|c|}{$\begin{array}{c}\text { Number of } \\
\text { lesions }\end{array}$} & \multicolumn{2}{|c|}{$\begin{array}{l}\text { Diameter of } \\
\text { lesion }(\mathrm{mm})\end{array}$} & \multicolumn{2}{|c|}{$\begin{array}{c}\text { Infected area } \\
\left(\mathrm{mm}^{2}\right)\end{array}$} & \multicolumn{2}{|c|}{$\begin{array}{c}\% \text { of } \\
\text { protection }\end{array}$} \\
\hline & & $\begin{array}{l}\text { At the } \\
\text { same } \\
\text { time }\end{array}$ & $\begin{array}{l}\text { One } \\
\text { day } \\
\text { later }\end{array}$ & $\begin{array}{l}\text { At the } \\
\text { same } \\
\text { time }\end{array}$ & $\begin{array}{l}\text { One } \\
\text { day } \\
\text { later }\end{array}$ & $\begin{array}{l}\text { At the } \\
\text { same } \\
\text { time }\end{array}$ & $\begin{array}{l}\text { One } \\
\text { day } \\
\text { later }\end{array}$ & $\begin{array}{l}\text { At the } \\
\text { same } \\
\text { time }\end{array}$ & $\begin{array}{l}\text { One } \\
\text { day } \\
\text { later }\end{array}$ \\
\hline \multirow{7}{*}{ Garlic } & 0 & 6 & 6 & 6.04 & 6.04 & 171.8 & 171.8 & 0 & 0 \\
\hline & 10 & 0.083 & 2.65 & 0.013 & 1.33 & 0.01 & & 99.9 & 97.78 \\
\hline & 20 & 0 & 1.16 & 0 & 0.41 & 0 & 0.1 & 100 & 99.89 \\
\hline & & 0 & 0.083 & 0 & 0.026 & 0 & 0.0003 & 100 & 99.99 \\
\hline & & 0 & 0 & 0 & 0 & 0 & 0 & 100 & 100 \\
\hline & Mean & 1.21 & 1.97 & 1.21 & 1.56 & 34.36 & 35.15 & 79.98 & 79.53 \\
\hline & 0 & 6 & 6 & 6.04 & 6.04 & 171.8 & 171.8 & 0 & 0 \\
\hline \multirow[t]{5}{*}{ Ginger } & & 2.66 & 5.25 & & 5.33 & 13.00 & & 92.59 & 31.9 \\
\hline & 2 & 0.5 & 4.16 & 1.02 & 4.00 & 0.42 & 52. & 99.74 & 69.43 \\
\hline & & 0.83 & 2.2 & 0.14 & 3.27 & 0.009 & & 99.99 & 88.60 \\
\hline & 100 & 0 & 1.41 & 0 & 1.37 & 0 & 2.08 & 100 & 98.78 \\
\hline & Mean & 1.99 & 3.81 & 1.90 & 4.00 & 37.04 & 72.56 & 78.46 & 57.74 \\
\hline \multicolumn{2}{|r|}{ at 5\% } & 0.59 & 0.39 & 0.29 & 0.48 & 2.83 & 5.83 & 0.79 & 3.24 \\
\hline
\end{tabular}

Under detached leaf technique, all tested plant extracts decreased disease severity and percentage of infection. Disease severity decreased with the increasing plant extract concentrations. Garlic was the most effective on decreased disease severity $(24.19 \%)$ and percentage of infection $(60.83 \%)$, followed by ginger (36.88\% and $77.02 \%)$ Table, 11 . Garlic reduced the disease severity and percentage of infection $(55.63 \%$ and $35.94 \%$ ), followed by ginger $(32.33 \%$ and $18.90 \%)$, respectively. The inhibitory effect of the tested extracts might be due to natural bioactive materials presented in these extracts (Khalil, 2001).

Generally, garlic extract was the most effective extract used against the pathogen of tomato early blight disease. This might be due to garlic extract through presence of antimicrobial compound that were described mainly as allicin (allyl-2-propenethiosulfinare) which is generated from alliin (Sallylcystein-S-oxide) after injury of the garlic tissue is a rather labile compound and is further transformed into a variety of substance. The volatile 
organic compounds mainly consisted of linear chain aldehydes (5-hexenal, and octanal), allylsulfides, and disulfides (allyl disulfide allyl methyl disulfide) (Shalaby and Atia, 1996 and Ahmed et al., 2009).

Table (11): Effect of plant extracts concentration on tomato early blight disease incidence using intact leaves under greenhouse conditions.

\begin{tabular}{lccccc}
\hline $\begin{array}{l}\text { Plant } \\
\text { extracts }\end{array}$ & $\begin{array}{c}\text { Concentration } \\
(\%)\end{array}$ & $\begin{array}{c}\text { Disease } \\
\text { severity }\end{array}$ & $\begin{array}{c}\text { Disease } \\
\text { severity } \\
\text { (Reduction) }\end{array}$ & $\begin{array}{c}\text { Percentage } \\
\text { infection }\end{array}$ & $\begin{array}{c}\text { Percentage } \\
\text { infection } \\
\text { (reduction) }\end{array}$ \\
\hline \multirow{4}{*}{ Garlic } & $\mathbf{0}$ & 54.59 & 0 & 95.06 & 0 \\
& $\mathbf{1 0}$ & 26.57 & 51.33 & 67.03 & 29.40 \\
& $\mathbf{2 0}$ & 18.19 & 66.59 & 59.18 & 37.66 \\
& $\mathbf{5 0}$ & 13.18 & 75.76 & 49.33 & 47.98 \\
& $\mathbf{1 0 0}$ & 8.44 & 84.47 & 33.58 & 64.7 \\
\cline { 2 - 6 } & Mean & 24.19 & 55.63 & 60.83 & 35.94 \\
\hline \multirow{4}{*}{ Ginger } & $\mathbf{0}$ & 54.59 & 0 & 95.06 & 0 \\
& $\mathbf{1 0}$ & 40.02 & 26.55 & 82.21 & 13.36 \\
& $\mathbf{2 0}$ & 34.08 & 37.46 & 74.65 & 21.37 \\
& $\mathbf{5 0}$ & 30.04 & 44.84 & 69.14 & 27.22 \\
& $\mathbf{1 0 0}$ & 25.68 & 52.81 & 64.04 & 32.59 \\
\hline L.S.D at 5\% & Mean & 36.88 & 32.33 & 77.02 & 18.90 \\
\hline
\end{tabular}

Othman et al., (1991) and Satya et al., (2005), proved that the crude antiphytoviral of garlic bubbliest was thermos-table. Also this study revealed that fungi-toxic compounds were presented in ginger and garlic since they were able to inhibit the growth of the fungus tested. This agrees with earlier reports of (Udo et al., 2001) on the inhibition of growth. It was shown that antifungal substances found in the Eucalyptus species examined consist of from 1 to 4 different components (Balandrin et al., 1985). Cinnamon, halfa barr, laurel and ginger plant extracts with either cold distilled water (CDW) or boiling (BDW) had a strong antifungal activity with significant inhibition on the growth and hydrolytic enzymes (glucosidase, pectinlyase and protease) of $A$. alternata and F. oxysporum (Fawzi et al., 2009).

\section{REFERENCES}

Ahmed, Amal, A.M.; M. M.M. Atia; M.I.Abou-zaid and M.R.A. Tohamy (2009). Pathological studies on tomato early blight. Zagazig J. Agric. Res., Vol. 36 No. (1).

Ahmed, M.A. and E.A. Saleh (1991). Phyllosphere microflora of tomato leaves and their antagonistic activity against Alternaria solani. Annual Agriculture, Faculty of Agriculture, Ain Shams University (1987) 106122.

Aly, A.Z.; Buchenauer, H.; Abou-Zaid, M.I.; Shalaby, M.S. and M.M.M. Atia (2002). Induced resistance against tomato late blight disease by using biological agents. Egyptian J. Phytopathology, 30: 25-43- Egypt. 
Ashrafuzzaman, M.H.; A.R. Khan and A.R. Howlider (1990). In vitro effect of lemongrass oil and crude extracts of some higher plants on Rizoctonia solani. Bangladesh Journal of Plant Pathology, 6: 17-18.

Atia, M.M.M. (2000). Studies on tomato late blight caused by Phytophthora infestans. Ph. D. in PI. Path., Fac. Agric., Zagazig Univ., Egypt.

Atia, M.M.M. (2005). Induction of resistance to alternaria leaf blight (Alternaria cucumerina) in melon plants by DI-ß-amino-n-butyric acid. Zagazig J. Environmental Res. Vol. 6: 85-104, Zagazig Univ., Egypt.

Atia M.M.M.; Aly, A.Z.; Buchenauer, H. and M.I. Abou-Zaid (2003). Mechanisms of $3 A B A$ induced resistance response of tomato to Phytophthora infestans. First International Conference on Biotechnology and Environmental, 14-15 April 2003-Zagazig Uni., Zagazig, Egypt.

Atia, M. M.M.; H. Buchenaue; A. Z. Aly and M.I. Abou-Zaid (2005). Antifungal activity of chitosan against Phytophthora infestans and activation of defence mechanisms in tomato to late blight. Biological Agriculture and Horticulture 23: 175-197

Bahaskara, R.; M.V. Angers; F. Castaigne and J. Arual (2000). Chitosan effects on black mold rot and pathogenic factors produced by Alternaria alternate in postharvest tomatoes. J. Amer. Soc. Hort. Sci. 125(6): 742747.

Balandrin, M.F.; J.A. Klocke; E.S. Wurtele and W.H. Bollinger (1985). Natural plant chemicals: Sources of Industrial and Medicinal materials. Science, 228: 1154-1160.

Benhamou, N.; Kloepper J. W. and S.Tuzun (1998). Induction of resistance against Fusarium wilt of tomato by combination of chitosan with an endophytic bacterial strain: ulterastructure and cytochemistry of the host response. Planta, 204: 2, 153-169.

Brame, C. and J. Flood (1983). Antagonism of Aureobasidium pullutans towards Alternaria solani. Trans-ations of the British Mycological Society, 81: 621-624.

Casida, L.E. and JR. F.L. Lukezic, (1993). Control of leaf spot diseases of alfalf and tomato applictions of the bacterial predator pseudomonas strain 679-2. Plant Disease (1992) 76(12): 1217- 1220.

Chaerani, R., G. Remmelt, P. Stem, E. Roeland and Voorrips (2007). Assessment of early blight (Alternaria solani) resistance in tomato using a droplet inoculation method. Journal of General Plant Pathology (2007) 96-103.

Chaturvedi R. and J. Shah, (2007). Salicylic acid in plant disease resistance. Salicylic Acid: A plant Hormone 335-370.

Chet, I.; N. Benhamou and S. Haran (1998). In Trchoderma and Gliocladium (eds Kubicek, C.P. \& Harman, G.E.) Taylor and Francis, London, 2: 153-172.

El-Abyad, M.S., M.A. El-Sayed; A.R. El-Shanshoury and S.M. El-Sabbagh, (1993). Twards the biological control of fungal and bacterial disease of tomato using antagonistic Streptomyces spp. Plant and soil. (1993) 149(2): 185- 195. 
El-Farnawany, M.A. (2006). Effect of seed treatment with Trichoderma harzianum on reducing tomato early blight incidence. Assiut-Journalof-Agricultural-Sciences. (2006) 37(1): 201-216.

El-Ghaouth, A.; J.Arul; J. G renier; N. Benhamou; A. Asselin and R. Belanger, (1994). Effect of chitosan on cucumber plants: suppression of Pythium aphanidermatum and induction of defense reaction. Phytopathology, 84, 313-320.

El-Naggar, M.A. (1997). Effect of some plant extracts as germicides on controlling powdery mildew disease of pepper under plastic house. $8^{\text {th }}$ Cong. Egypt. Phytopathol. Soc., Cairo, PP. 173-185.

Esh; A. M. H., Atia, M.M.M. and Taghian, Shadia (2010). Detection of systemic resistance in sugar beet eliciated by non-pathogeenic, phyllosphere-colonizing Bacillus pumilus and $B$. subtilus against the pathogen Cercospora beticola Saac. Egyptian J. Appl. Science, 25: 340-361.

Fawzi, E. M.; Khalil, A. A. and A. F. Afifi (2009). Antifungal effect of some plant extracts on Alternaria alternate and Fusarium oxysporum. African Journal of Biotecnology; 8(11):2590-2597.

Gaffney, T.; Friedrich, L.; Vernooij, D.; Nye G.; Uknes, S.; Ward, E.; Kessmann, H. and J. Ryals (1993). Requirement of salicylic acid for the induction of systemic acquired resistance. Science 261: 754-756.

Gilardi, G.; D.C. Manker; M. Benuzzi; A. Garibaldi and M.L. Gullino (2008). Efficacy of Bacillus subtilis and Ampelomyces quisqualis alone and in combination with fungicides against Podosphaera xanthii of zucchini. Journal of Plant Pathology 90: 268.

Hafez,Y. H. (2008). Effectiveness of the antifungal black seed oil against powder mildews of cucumber (Podosphaera xanthii) and barley (Blumeria graminis f. sp. hordel). Acta Biologica Szegediensis; 52(1):17-25.

Handlesman, J. and J.I. Park (1989). Mechanism in biocontrol of soilborne plant pathogens iv Vogue, T. Nester E. W. (eds). Plant microbial interaction, Vol.3 New York McGrwohill 1989, pp. 27-61.

Harman, G.E. and C.P. Kubicek (1998). Trichoderma and Gliocladium Taylor and Francis, London, Vol. 2.

Holt, J. G.; N.R. Krieg; P.H. Sneath; J.T. Staley and S.T. Williams (1994). Bergey's Manual of Determinative Bacteriology $9^{\text {th }}$ ed. Williams and Wilkins Co. USA.

Inbar, M.; Doostdar, H.; Sonoda, R.M.; Leibee, G.L. and R.T. Mayer (1998). Elicitors of plant defensive system reduce insect densities and disease incidence. J. Chem. New York 24 (1): 135-149.

Jensen, H.L. (1930). Actinomycetes in Danish soils. Soil Science, 30:59-77.

Jindal, K. K.; Singh, H.; Madhu, Meeta, and Meeta, M. (1988). Biological control of $P$. infestans on potato. Indian J. of PI. Pathology, 6: 1, 59-62. (c. f. CAB Abstracts 1990-1991).

Ju, K. H.; S.H. Lee; C.S. Kim; E.K. Lim; K. Choi; H.G. Kong ; D.W. Kim; S. Lee and B. Moon (2007). Biological control of strawberry gray mold caused by Botrytis cinerea using Bacillus licheniformis N1 formulation. Journal of Microbiology and Biotechnology, 17: 438-444. 
Kessmann, H.; T. Staub; C. Hoffmann; T. Maetzke; J. Herzog; E. Ward; S. Uknes and J. Rayals (1994). Induction of systemic disease resistance in plants by chemicals. Review of Phytopathology, 32, 439-459.

Khalil, A.R.M. (2001). Phytofungitoxic properties in the aqueous extracts of some plants. Assiut J. Agricult. Sci., 32: 135-143.

King, E.O.; M.K. Wared and D.E. Raney (1945). Two simple media for the demonstration of Pyocyanin and fluorescein. Journal of Laboratory and Clinical Medicine, 44: 301-307.

Klessig, D.F. and J. Malamy (1994). The salicylic acid signal. PI. Mol. Biol. 26: 1439-1458.

Liao, Ma, Guorui and G. Hong, (2003). Induction effect of chitosan on suppression of tomato early blight and physiological mechanism. Journal of Zhejiang University Agriculture and life sciences. 2003; 29(3): 280- 286.

Liu, N. and E. Wu, (1997). Chemical and biological control of tomato early blight. Plant pathology. Bulletin 1997 6(3): 132- 140.

Lotfy, Maisa, A. (1996). Studies on the biological control of Sclerotium rolfsii. M.Sc. Thesis, Fac. Agric., Zagazig Univ., Zagazig.

Metha, P.; K.M. Vyas and S.B. Saksena (1975). Production of pectolytic enzymes by Alternaria solani and Alternaria tenuis on different culture media. J In Bot Soc., 54:200-206.

Nair, K.R.S. and A.H. Ellingboe (1962). Method of controlled inoculations with coindiospores of Erysiphe graminis var. tritici. Phytopathology, 52:714.

Othman, B.A.; K.H. EL-Dougdoug and M. Abo-EL-Nasr (1991). Effect of garlic bubbilies extraction on tomato mosaic virus. Annals Agric. Sci., 36 (2): 423-430.

Pandey, K.K.; P.K.Pandey; Gautam-Kalloo and M.K. Banerjee (2003). Resistance to early blight of tomato with respect to various parameters of disease epidemics. Journal-of-General-Plant-Pathology. 2003; 69(6): 364-371.

Peniston, Q.P and E. Johnson (1980) Process for the manufacture of chitosan. US Patent, 5 (4): 195- 175.

Prasad, Y. and M.K. Naik (2003). Evaluation of genotypes, Fungicides and plant extracts against early blight of tomato caused by Alternaria solani Indian Journal of plant protection, 31(2): 49- 53.

Reni, C.; G. Remmelt; S. Piet and E.V. Roeland (2007). Assessment of early blight (Alternaria solani) resistance in tomato using a droplet inoculation method. Journal of General Plant Pathology, 2 (73): 96-103.

Qasem, J.R. and H.A. Abu-Blan (1996). Fungicidal activity of some common weed extracts against different plant pathogenic fungi. J. Phytopathol. 144: 157-161.

Satya, V.K.; R. Radhajeyalakshmi; K. Kavitha; V. Paranidharan; R. Bhaskaran and R. Velazhahan (2005). In vitro antimicrobial activity of zimmu (Allium sativum L., Allium cepa L.) leaf extract. Archives of Phytopathology and Plant Protection, 38 (3): 185-192. 
Schirmböck, M.; M. Lorito; Y.L. Wang; C.K. Hayes; I. Arisan-Atac; F. Scala; G.E. Harman and C.P. Kubicek (1994). Parallel formation and synergism of hydrolytic enzymes and peptaibol antibiotics, molecular mechanisms involved in the antagonistic action of Trichoderma harizianum against phytopathogenic fungi. Appl. Environ. Microbial. 60, 4364-4370.

Shalaby M.S. and Atia, M.M.M. (1996). Pathological studies on root-rot of watermelon and cantaloupe in the reclaimed soils. Zagazig J. Agric. Res. Vol. 23 (4): 505-515, Egypt.

Snedecore, G.W. and W.G. Cochran (1982). Statistical methods $7^{\text {th }}$ Ed. lowa state University, Pres Ames USA.

SPSS, (1997). User's guide statistics. Version 8 Copyright SPSS Inc. USA.

Suli, D.; E. Pajot and Y. Cohen (2002). Induction of resistance to powdery mildew (Peronospora parasitica) in cauliflower by DI-ß-amino-nbutanoic acid (BABA). PI. Path. 51: 97-102.

Surviliene, E.; A. Brazaityte and A. Sidlauskiene (2003). Effect of benzotiadiazole on phytopathological and physiological processes in tomato. Zemes ukio mokslai, (2003) (1): 34- 40.

Suwitchayanon, P. and K. Kunasakdakul (2009). In vitro effects of clove and turmeric extracts controlling crucifer pathogens. Journal of Agricultural Technology; 5(1): 193-199.

Taghian, Shadia; A.M. Esh; A.Z. Aly and M.R.A. Tohamy (2008). Bacillus subtilis as bioagent used to control cercospora sugar beet leaf spot disease. Zagazig J. Agric. Res., Vol. 35 (6) 1347-1360.

Thiribhuvanamala, G.; G. Ramakrishnan and L. Sabitha (2001). Effect of plant products agents Alternaria solani, the early blight pathogen of tomato. South Indian Horticulture, 49:257- 260.

Trejo, S.; R. Estrad; A. Paszczynski and D.L. Crawford (1998). Antibiotics and enzymes produced by the biocontrol agent Streptomyces violaceusniger YCED-9. J. of Industrial Microbiology and Biotechnology. 21: 1-2, 81-90. (c.f. CAB abstracts 1998/8-1999/01).

Udo, S.E.; B.E Madunagu and C.D. Lsemin (2001). Inhibition of growth and Biological sporulation of fungal pathogens on Sweet potato and yam by Garlic. extract. Nigeria. J. Bot., 14: 35-39.

Van Loon, L.C.; P. A. Bakker and C.M.J. Pieterse (1997). Mechanisms of PGPR-induced resistance against pathogens. In: Ogoshi, A., Kobayashi, K.; Homma, Y.; Kodama, F.; Kodo, N. and S. Akino, (1997). Plant growth promoting rhizobacteria. Present status and future prospects. Proc. $4^{\text {th }}$ Intern. Sapporo, Japan, October 5-10, 1997.

Ward, E.R.; S.J. Ulknes; S.C. Williams; S.S. Dincher; D.L. Wiederhol; D.C. Alexander; P. Ahl-Goy; J.P. Metraux and J. Ryals (1991). Coordinate gene activity in response to agents that induce systemic acquired resistance. Plant Cell 3:1085-1094.

Yahia, A. H.; Dawlat A. Abed El-Kader, Dorreiah E. Salem and A.A. Sayed Ahmed (1990). Biological soil treatment with $T$. harzianum to control brown stem rot of soybean. Egypt. J. Phytopathology. 
Yalpani, N.; Silverman, P.; T.M.Wilson; D.A. Kleier and I. Raskin (1991). Salicylic acid is a systemic signal and an inducer of pathogenesisrelated proteins in virus-infected tobacco. Plant Cell, 3: 809-818.

Yusran, Y.; M. Weinmann; T. Müller and V. Römheld (2008). Biological control of fusarium crown and root rot disease in four varieties of tomato using Pseudomonas fluorescens and Bacillus amyloliquefaciens. ii. Seedling infection and disease severity. Journal of Plant Pathology 90: 427

Zhanyong, C.; C.H. Rong; X. Rouge; L. Song; Yu. Huahua; W. Pibo Cuiping; L.L. and L.L. Pengcheng (2006). Novel derivatives of chitosan and their anti-fungal activities in vitro. Carbohydrate Research 341: 351-354.

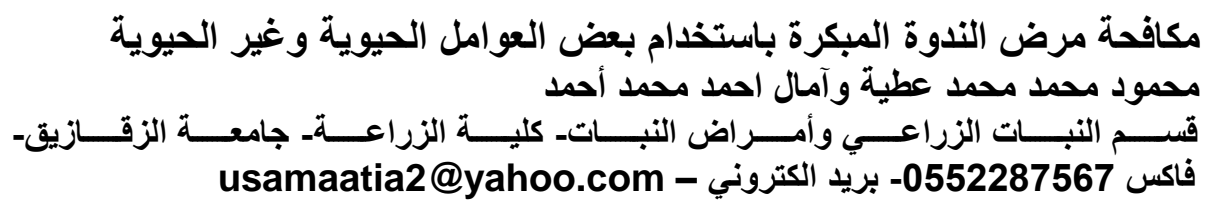

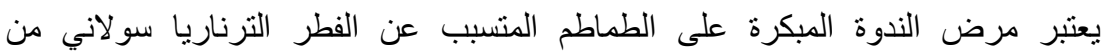

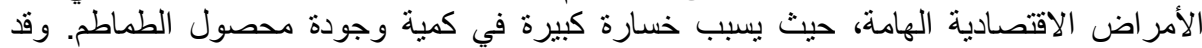

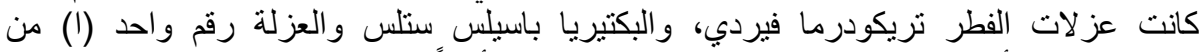

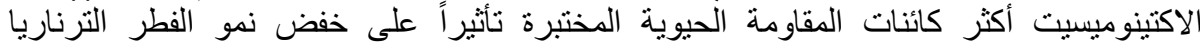

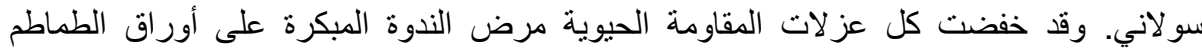

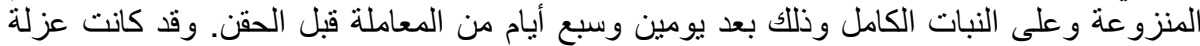

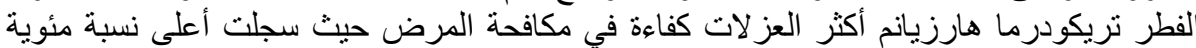

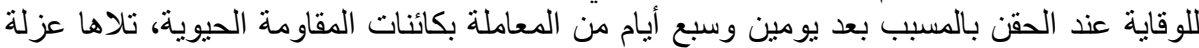

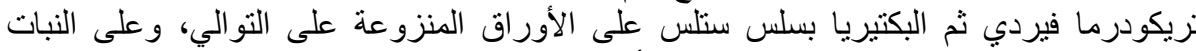

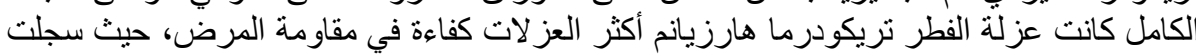

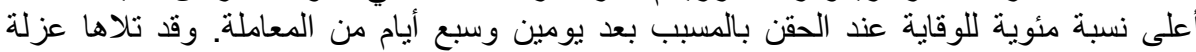

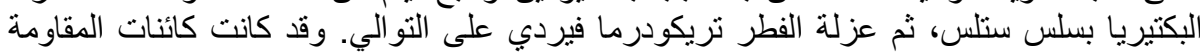

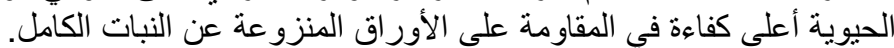

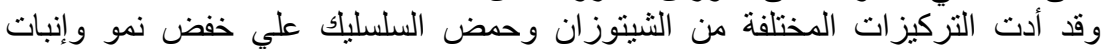

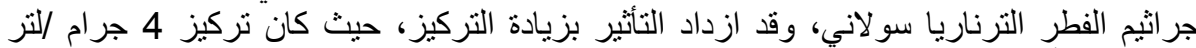

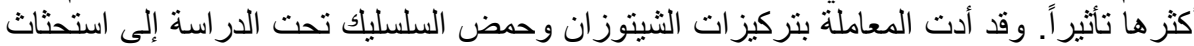

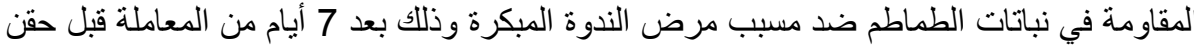

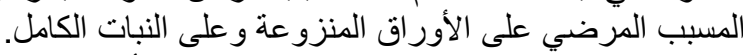

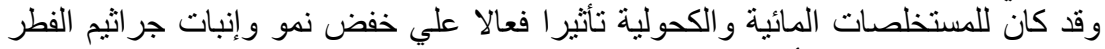

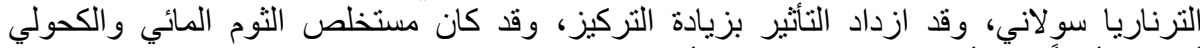

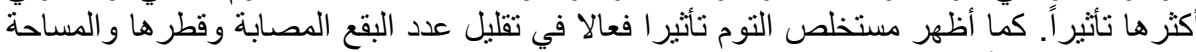

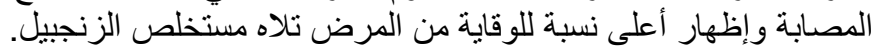

كلية الزراعة - جامعة المنصورة مركز البحوث الزراعية
قام بتحكيم البحث

أ.د / ألسيدعبد المجيد فيظ الله

أ.د / أحمد زكي علي الحيد 